\title{
The Impact of the Economic Crisis on Youth Employment in Slovenia
}

\author{
Jasmina Žnidaršič, Mojca Bernik, Miha Marič \\ University of Maribor, Kranj, Slovenia
}

\begin{abstract}
Companies in Slovenia have implemented a number of measures to cope with the recent economic crisis and to adapt to market conditions. One of these measures has been eliminating jobs and reducing the number of employees. This led to an expansion in the number of unemployed, while the number of newly employed people has decreased. We have examined the problem of the employability of young people who are seeking employment and are often without the experience necessary for the work place. The aim was to make a systematic review of the programs for promoting youth employment that are carried out in Slovenia and that may reduce the number of unemployed youth. Youth unemployment in Slovenia for the years of 2008 and 2009 is also presented.
\end{abstract}

Keywords: employment, unemployment, youth, education, crisis

\section{Introduction}

Changes occurring in the economic and social sphere, often affect young people first and foremost. Youth in the modern society grapple with the creation of everyday life, value systems and finding a balance between their personal desires and expectations as well as social requirements and opportunities. Within the dynamics of transitions between the different situations of young people, the transitions from education to employment remain the most demanding and critical.

Trends in the youth labor market are heavily dependent on current economic and social developments in the country. The youth labor market shares the fate of the entire labor market. However, it has some important unique features that specifically impact the situation of youth in the labor market and in society at large (Ignjatovič \& Trbanc, 2009). Only a successful transition into comparatively stable employment actually establishes youth in the position of equal members of society, since employment predominantly ensures social-economic independence and simultaneously gives them the possibility of long-term planning for life, career, family, living conditions etc.. Therefore, youth unemployment is not a problem only in terms of placement in the system of work and future career opportunities of young people, but also in the form of negative psychological and broader social consequences (Trbanc, 2007b).

The employability of young people or first-time jobseekers is a major problem in Slovenia, as well as throughout the European Union. Since the start of the current economic crisis, the situation in the labor markets

Jasmina Žnidaršič, MA, Assistant, Faculty of Organisational Sciences, University of Maribor.

Mojca Bernik, Ph.D., Assistant Professor, Faculty of Organisational Sciences, University of Maribor.

Miha Marič, MA, Assistant, Faculty of Organisational Sciences, University of Maribor.

Correspondence concerning this article should be addressed to Jasmina Žnidaršič, Faculty of Organizational Sciences, Kidričeva cesta 55a, 4000 Kranj, Slovenia. E-mail: jasmina.znidarsic@fov.uni-mb.si. 
has become even worse, because one of the measures implemented by companies facing with this difficult situation, and adapting to market conditions was the elimination of jobs and reducing the number of surplus employees. This led to an increase in unemployment and greatly diminished the possibility of employability. A particularly vulnerable group in the current difficult situation is youth, because after graduating they do not have the adequate work experience for immediate employment in companies and are therefore difficult to recruit. This not only includes those with low education, but also those with higher education. For example, the average duration of job search of a graduate in Slovenia was 10 months in 2009.

The purpose of this paper is to highlight the situation of youth in the Slovenian labor market, focusing on current trends and issues that they are facing. We will also examine programs aimed at solving youth unemployment.

\section{Youth and Social Changes}

Changes occurring in the economic and social sphere often affect young people first and foremost (Ule, 2007). The term "youth" is usually used for people during the period from childhood to maturity. Young people represent a specific part of the society, and they are a group that reflects the past demographic patterns, as well as current and future social trends of economic indicators (Vertot, 2009; Trbanc, 2007b).

The European Commission's White Paper (COM, 2001) is based on the findings of demographic research, which indicated that youth today lasts longer because under the pressure of economic and socio-cultural factors, young people, on average, achieve different levels of living later, including the end of formal education, first job, a family etc.. Moreover, one's way of life is not as straightforward today, as different roles are interwoven.

Ule (2007) argues that lengthening the period of education also extends the period of youth dependency or semi-dependency on original families, which is especially noticeable in Slovenia. Young people in modern society are placed in a contradictory situation. On the one hand, they are forced into earlier and more informed choices (on the kinds and natures of education, leisure, early planning of life paths etc.), which implies a shift of responsibility for their own lives in childhood (Rener, 2007). On the other hand, the period of education and economic independence has been extended, which is a sharp contrast to the requirements of the early choices and taking responsibilities (Ule, 2007). Additionally, currently noticeable changes are also in the values and life orientations of youth. In particular, a noticeable shift is from the importance of material goods to focusing on immaterial "goods" such as relations, friendship, leisure, creativity, pleasure and self-realization. Such immaterial goods are increasingly gaining importance, even if that means a slightly lower income.

Sociologists and researchers do not have identical views on the definition of youth, nor its age limit. Some believe that young people are those aged between 15 and 25 years, others extend the upper age limit to 30 years, some even longer. The United Nations normally takes into account the definition of "youth" formed in the International Year of Youth in 1985, which defined "youth" as all young people aged between 15 and 24 years. The Statistical Office of the Republic of Slovenia (SORS) and some other European countries define youth as young people, aged from 15 to 29, and in most European countries, the upper age limit does not exceed 30 years (Vertot, 2009). From this point of view, the collection, comparison, analysis and interpretation of data on young people often represent a methodological problem. We will use the definition of youth that the Employment Service of Slovenia uses, which defines youth as people below 26 years old. 


\section{Labor Market in Slovenia}

\section{Demographic Indicators of Slovenia}

The demographic situation in Slovenia is strongly characterized by five determinants: population growth, ageing population, lowering fertility, declining mortality and increasing migration. In this context, in the most recent decade, Slovenia has been marked by demographic extremes, because it has experienced both declining fertility rates and life prolonged life spans (Boljka, 2009). An important indicator of labor market is also the unemployment rate of youth (Ignjatovič \& Trbanc, 2009).

\section{Unemployment in Slovenia}

Unemployment is defined in the resolution relating to statistics of the economically active population, employment, unemployment and underemployment, adopted by the Thirteenth International Conference of Labour Statisticians in 1982 in Geneva. As the "unemployed" are defined all persons above a specified age who are during the reference period of "without work", i.e., those who are not in paid employment or self-employment as defined in paragraph; "currently available for work", i.e., those who are available for paid employment or self-employment during the reference period; and "seeking work", i.e., those who have taken specific steps in a specified recent period to seek paid employment or self-employment (LABORSTA Internet: Main statistics (annual)-Unemployment (E), March 27, 2010). The prevalence of unemployment is measured by using the unemployment rate, which is defined as the percentage of those in the labor force who are unemployed (Blanchard, 2005). Legislation in the field of employment in Slovenia is presented in Appendix A.

Economists distinguish different types of unemployment: cyclical unemployment, frictional unemployment, structural unemployment and classical unemployment. Occasionally also mentioned are seasonal unemployment, hardcore unemployment, and hidden unemployment. Real-world unemployment is usually the combination of different types (Sullivan \& Sheffrin, 2003).

The decline of employment in Slovenia, which started in the last quarter of 2008, continued throughout 2009. According to the Office for Macroeconomic Analysis and Development, employment declined slightly slowed towards the end of 2009, but at an annual level, it remained high. On average, the level of formal employment fell by $2.4 \%$ in 2009 . The decline in economic activity in 2009 was reflected in a decrease in labor demand. The number of vacancies and new jobs was, compared with the previous year, reduced by one third on average. The country intervened in the labor market by adopting two laws (Zakon o delnem subvencioniranju polnega delovnega časa, Ur.l. RS, št. 5/2009 \& Zakon o delnem povračilu nadomestila plače, Ur.l. RS, št. 42/2009) including a subsidy scheme for more than 80,000 employees (about $10 \%$ of the total number of employees), which consequently mitigated the decline in the number of employees. In addition, the decline in the number of economically active people was partially mitigated by active employment policy measures, for which the state provided more funds in 2009 than in the year before. Under these measures, approximately 13,000 unemployed people were employed. In 2009, there was also a noticeable rise in the number of unemployed first job seekers.

In Slovenia, there were 96,672 (9.1\%) people unemployed on the December 31, 2009, which is an increase of $45.9 \%$ when compared to the number of unemployed on the same date just the year before which was 66,238 (6.7\%). The total number of people who became unemployed in 2009 was 114,496 which is an increase of $61.7 \%$ in regard to the year before. Most of the unemployed stated the expiry of their fixed-term employment as the reason for their unemployment $(45,146)$; some lost their jobs because of bankruptcy or as permanently redundant workers $(31,620)$; there were also 16,994 first-time jobseekers and 20,736 persons who lost their jobs for other 
reasons (Zavod RS za zaposlovanje, 2010).

It is expected that by the end of 2010, employment will further reduce and unemployment will increase. Therefore, a 2.3\% decline in the number of employees is projected for the year 2010. Consequently, the number of unemployed will continue to rise and reach an average of approximately 105,000, while the unemployment rate is also expected to increase ( $7.2 \%$ of surveyed and $11.1 \%$ of registered unemployed). This will in effect cause even greater unemployment among young people (IMAD, 2010).

\section{Youth Employment Problems in Slovenia}

\section{Youth Labor Market in Slovenia}

The term "youth workforce market" was established in studies of labor markets decades ago. It identifies the segment in which youth are seeking their first job as well as the supply of jobs that employers are willing to offer to youth without work experience. Youth labor markets constitute the segment of the labor market that is most greatly exposed to different fluctuations, and where pressures for flexibility and adaptability are the greatest. At the same time, young people are often also the least protected sector of the workforce (Trbanc, 2007b).

The traditional form of employment for an indefinite period of time in Slovenia has increasingly been substituted by new forms of so-called less-assured employment (Vertot, 2009). Youth as job seekers are currently confronted with a more flexible, less secure forms of employment in comparison to the older work force, i.e., with fixed-term jobs, part-time jobs, with occasional or temporary jobs under contracts (Trbanc, 2007a). To some extent, the concept of work among youth has also recently changed, because many of them are seeking employment that allows a favorable balance between work and private life (Ule, 2007).

In the case of flexible employment forms, it is especially important to emphasize "student work" via student services that is liberally regulated Slovenia. Such student work has been and is often criticized as one of the key causes for high youth unemployment in Slovenia, because employers meet their needs for unskilled or less qualified workers with student labor. Indeed, for employers, this type of labor is the cheapest and the least demanding form of workforce engagement. At the same time, this form of work is certainly the reason for lengthening the period of education and massive enrollment in higher education because it offers many young people a way to "survive" for several years. In addition to the fear of unemployment after graduation, employers also encourage youth to this form of employment. However, most of the work in the so-called secondary segments typically does not provide experiences that would enable young people to move into appropriate employment. Work through the student services can be highlighted as a significant anomaly in the labor market in Slovenia (Kuhar, 2009; Ignjatovič \& Trbanc, 2009).

This year, the Ministry of Labour, Family and Social Affairs has prepared a draft document "The Law of Small Work-Expert Background and Positions", which presents changes in the practices of occasional and temporary student work. The new Act on Small Work should be defined in 2010 and is expected to cover the area of student work as well as increase control in this area. One of the reasons for this new regulation is the fact that student work represents an increasing segment of the Slovenian labor market (3.7\% in 2008) (Ignjatovič \& Trbanc, 2009).

Regarding the problem of youth labor market in Slovenia, we also have to highlight some problems directly related to this topic. This is primarily the social exclusion of relatively high proportion of young people who do not finish school, lengthening the period of education to avoid unemployment, a lack of skills and experience in seeking their first job, a mismatch of education with labor market requirements, regional development disparities 
affecting youth employment opportunities, and the brain drain of highly educated young people.

Society strives to become more educated and engaged in learning. The transition from education to the employment has changed dramatically in recent years. Several years ago, the majority of young people were recruited after finishing high school, while today young people increasingly continue education and thereby extend the transition time from education to employment. The problem is not just a long transition, but also the fewer opportunities for youth employment. Those who fail in obtaining employment in the transition become unemployed.

\section{The Consequences of Youth Unemployment}

Social exclusion and marginalization are usually indicated as the main consequence of unemployment, not only in the labor market, but also in other areas of life. Youth unemployment is a key risk factor that impedes young people's overall long-term involvement in society. Research findings also indicate that the accumulation of bad experiences of unemployment among youth contributes to economic deprivation, social isolation and the mental health problems (Rapuž, 2009).

Young people are exposed to the uncertainties in the form of great flexibility, which consequently leads to reduced ability of full economic and social independence because of uncertainty in the youth labor market (Boljka, 2009). Moreover, they remain a burden longer for their parents, leave home later and create their own families later. The result of this delay is also lowering the fertility rate, because there are fewer opportunities to have children (Kuhar, 2009). Fergusson, Horwood and Woodward (2001) argue that unemployment among youth is also associated to increasing risks of disorder. Results of the research showed that young people exposed to six months or greater unemployment in any given year had rates of mental health problems, criminal offense, substance use disorders and suicidal behaviors that were between 1.4 and 8.4 times higher than their non-unemployed peers.

The high rate of inactivity among young people (apart from the participation in education and training) and the failure to integrate into the labor market is usually associated with high overall unemployment (COM, 2007).

\section{Youth Unemployment in Slovenia}

Youth unemployment is of great concern worldwide. Only a few countries have managed to reduce youth unemployment, but in most, it still remains a chronic problem, and it is a major and an increasingly critical issue problem in Slovenia. Youth unemployment, especially for those searching for their first employment, is becoming an increasing problem as the number of young people who are searching for their first employment rose to 16,994 in 2009 from 12,517 in 2008 (Zavod RS za zaposlovanje, 2010).

According to the cause for the application to the Employment Service of Slovenia, unemployed young graduates are separated into two major groups: first-time job seekers and persons seeking re-employment. The fundamental difference is that the first-time job seekers usually do not have the seniority and are, on average, younger than those seeking re-employment (Verša \& Spruk, 2004).

As a particularly vulnerable group among unemployed youth, we should emphasize low-educated young people. Much attention has been recently devoted to this group since they have a difficult time competing with educated young people as well as with older people with lower education. The group that is currently increasing is (as previously mentioned) first-time job seekers without experience, among those who are especially critical are those seeking employment for more than six months or even longer than one year (Trbanc, 2007b).

\section{From Education to Employment}

In youth as a life period, the processes of social integration into one's main social role as well as 
establishment of one's own identity and achievement of a certain degree of autonomy happen. In these processes, the transition of young people from the field of education to field of work also plays an important role, and is often a turning point in the life of the individual. Successful transition into employment allows young people equal participation in society and ensures their independence, and additionally, enables them to achieve a specific social position (Verša \& Spruk, 2004).

Substantial changes in the transition of young people from the area of education to employment in modern society in general have occurred, because they are becoming increasingly complex and differentiated compared to the past (Rapuš, 2005). The transition from education to employment is also changing in Slovenia as a growing share of young people continue their education at the tertiary level, the age of young people in this transition is increasing, and the duration of the transition is longer and more uncertain. One characteristic of modern developments in the labor market is also the shifting from the labor market to training or learning and returning to the labor market, which is particularly significant for young people (Vertot, 2009).

Factors affecting the transition of young people from education to employment can be roughly divided into structural (e.g., demographic and economic factors), institutional (e.g., the structure of the education system, the relationship between educational institutions and employers, programs to promote youth employment etc.), and individual factors (e.g., knowledge, skills, values etc.) (Trbanc, 2007a).

Educational systems and more-or-less systematically arranged transitions from education to employment with an appropriate advisory support can significantly affect the pace of youth integration into employment (Ignjatovič \& Trbanc, 2009). Education systems should provide effective and appropriate education for life, together with the development of the individual's potential for creativity and autonomy, and at the same time avoid non-compliance with the labor market (COM, 2007).

By looking at the data of registered unemployment in Slovenia on December 31, 2009, we can see that there were 12,059 people below the age of 25 who were unemployed. Of these, the largest groups of unemployed young people were 3,704 with no education, 2,852 with secondary school (three years), and 4,287 with general secondary education (four years) (Zavod RS za zaposlovanje, 2010).

\section{Youth and Education in Slovenia}

A general finding is that youth with high education respond much more to changes in economic opportunities than those with low education levels. In some conditions, graduates are 10 to 20 times more responsive than non-graduates. Less-skilled youth are also being more constrained in their job opportunities than more-skilled youth (Ribar, 2001).

Access to education in Slovenia, compared with other European countries, is relatively favorable, because of the impact of socioeconomic status on educational opportunities for young people. Slovenia has a relatively high share of education expenditures in its GDP, compared with other EU members. The availability of education is influenced by various factors, such as the number of available places by level of education, the geographic distribution of educational institutions, the kind and level of funding of educational institutions and the forms of financial and non-financial assistance, such as various transfers to households. In comparison to other European countries, the involvement of young people in primary and secondary education in Slovenia is high and is increasing in accordance with the Lisbon Strategy and the strategy of Slovenia's development. The involvement of young people in tertiary education is also increasing. However, here we must highlight the problem of dropout rates in tertiary education (Rakar, 2009). The structure of Slovenia's education system is presented in Appendix B. 


\section{First Employment}

For young people, the end of school means the beginning of one's job search. First employment plays an important role in a young individual, since it represents an important milestone in life. It represents becoming independent and, at the same time, brings great responsibility and changes in lifestyle. Young people represent a special segment of jobseekers in the employment market, since they are entering the market for the first time and are largely without the necessary experience and, therefore, are less attractive as potential workers for employers. Many employers usually require someone with at least a few years of work experience, which young people do not yet have after finishing school. This represents a kind of a conflict in finding their first job. If the lack of experience in finding employment represents a significant negative point, it can also be a benefit as young job seekers have great flexibility, the ability and willingness to learn new skills, and they are responsive to both changes in the working process and new demands at their work place.

The key competitive advantage of the young labor force is the most recent and complex knowledge they bring with them from the educational process that they have recently completed. In addition, young people possess (to a greater extent than the older workforce) competences and skills for which the employers have demand (e.g., computer skills, language skills etc.). Upon entering the labor, the increasing competition among highly educated young people with many competences market is very intense. This leads to highly educated young people being confronted with unemployment. Those who leave school early are at a disadvantage to older low-skilled labor on the employment market. The lack of work experience is most frequently mentioned as a major competitive disadvantage of young workers, which is often one of the most important conditions for employment (Trbanc, 2007a).

In the analysis of individual transitions of young people to adulthood in Slovenia, the prolonging of all transitions stands out. Apart from the fact that the period of adolescence is extended to longer periods because of education, the average age at first employment is also raised (Trbanc, 2007a).

Young people believe that employment is the best way to integrate themselves into society. In doing so, they expect guidelines that will lead them to finding their own place on the long term in the world of employment, because having a job means being an adult, having self-esteem, money, independence, and represents the opportunity to expand social contacts (Vaupotič, Lukić, Bajde, Perko, \& Golob, 2007). Of those young people searching for their first employment, 7,462 found it in 2008 and 6,016 found it in 2009. These are very low numbers compared to the data on there were how many searching for it in the selected years. The rate of unemployment among those who are searching for their first employment was 14.3\% in 2009 (Zavod RS za zaposlovanje, 2010)

\section{Youth Employment Policy}

\section{EU Support for Youth Employment Policies}

The European Union and its member states, of which Slovenia is one, have given (in a joint effort to reduce and prevent unemployment) a clear priority to young people as the main target group. Employment guidelines relate to a new start that can offer employment to a person before being unemployed for six months (Vaupotič, 2007). Employment policies focus more attention on young people, among which are not just employment measures aimed at first-time job seekers and unemployed young people, but also the meaning and place that the issue of youth employment has in employment policies (Ignjatović \& Trbanc, 2009).

In 1995, the United Nations General Assembly adopted a set of recommendations to regulate youth policy. 
This served as the basis for the preparation of national youth policies in many countries. In European countries, the preparation of strategies for youth has been based particularly on the Council of Europe's Resolution issued on April 16, 1998, and the European Commission's White Paper on Youth ("A New Impetus for European Youth") of 2001 (Vertot, 2009). Since the adoption of the latter, a framework, with the support of the European Parliament and other institutions, has been progressively established for the policies relating to the young people. In 2005, the EU Member States within the framework of the European Youth Pact committed to give special attention to young people in the frames of the Lisbon strategy. The EU plays a complementary role by offering financial support and coordinating the policies of its member states (COM, 2007). An effective process of implementation of youth employment strategies should be based on five fundamental principles proposed by the European Commission's White Paper "A new impetus for european youth: Openness, participation, accountability, efficiency and consistency" (Ćeklić, 2008).

The European Employment Strategy plays the leading role in achieving goals in the area of the labor market and employment (including that of youth). The aim of this strategy is to adopt a framework of common employment-policy objectives, based on four pillars: employment opportunities, entrepreneurship, adaptability and equal opportunities. The EES operates at the EU level, where annual guidelines for employment policies and recommendations to Member States are designed. At the national level, the strategy primarily establishes national mechanisms to achieve the objectives in the area, improving the cooperation between all key actors in the system, development of monitoring systems and similar. At the regional and local levels, there are ongoing local employment programs, initiatives and activities of the European Social Fund (ESF), which include local projects and programs (Baloh Plahutnik, 2003).

In formulating employment policies at the national level, the government of Slovenia has used the four main European documents: the Lisbon Strategy, the European Pact for Youth (a proposal that is designed to ensure bringing the Lisbon strategy closer to younger people), the European Commission's White Paper "A New Impetus for European Youth", and the Revised European Charter on the involvement of young people in local and regional life (Vaupotič, 2007).

At the beginning of drawing the European funds as an EU Member State, Slovenia prepared a policy document: the National Strategic Reference Framework 2007-2013, which defines the purposes of drawing European funds. The document is the basis for operational programs that specifically define the scope of co-financing from the European Regional Development Fund, the European Social Fund and the Cohesion Fund. The programs, which are partly financed by EU funds and as a target group include young people are: the Programs of Measures to Promote Entrepreneurship and Competitiveness for the period 2007-2013, the Operational Programme for Human Resource Developments for the period 2007-2013, various regional development programs, the partnership program "Young People in the World of Work" for the period 2007-2013 and the Program of Active Employment Policy for the period 2007-2013 (Vaupotič, 2007).

\section{Programs for Solving Youth Unemployment in Slovenia}

The ministry responsible for the development of employment policies at the national level is the Ministry of Labour, Family and Social Affairs. The Ministry pursues two priority goals, i.e., the increase of youth employability and the reduction of structural imbalances in the labor market, which are mainly linked to the acquisition of formal and informal education. On this basis, it cooperates with the two ministries responsible for education, i.e., the Ministry of Higher Education, Science and Technology and the Ministry of Education and 
Sport (Vaupotič, 2007). In employment policies, the ministry is also working closely with the Employment Service of Slovenia, which is the national employment office. The Office of Youth under Ministry of Education and Sport has the responsibility for the development of youth policies and youth employment in Slovenia.

The state plays a major role in solving youth unemployment, in particular by facilitating access to employment with appropriate measures, incentives and awareness of employers about the benefits of employing youth as labor. Measures and incentives to tackle unemployment are summarized in active employment policies, which represent key state interventions in the labor market and are targeted at specific groups of people. In accordance with EU guidelines and recommendations of various international organizations, the transition from passive to active measures is increasingly emphasized (Južnik, 2008).

We will present the Active Employment Policy Programme for the period 2007-2013, in which one of the key target groups are young people, and two programs aimed at young job seekers.

\section{The Active Employment Policy Programme}

The Active Employment Policy Programme (AEP) has been designed to assist in obtaining employment for the unemployed and for the preservation of threatened jobs. The AEP is especially intended for those target groups that face any handicap to entering into the labor market (Baloh Plahutnik, 2003). The Active Employment Policy Programme for the period of 2007-2013 is derived from the priorities identified in the European and national development documents and is based on the labor market situation in Slovenia. The conceptual framework of the AEP is derived from Slovenia's Development Strategy, the National Reform Programme for implementing the Lisbon Strategy in Slovenia and the framework of economic and social reforms for increasing welfare in Slovenia. The program is partly financed from the state budget and the rest of the money is obtained from European funds, principally from the European Social Fund. The main actions under the AEP are providing advice and job search assistance, training and education, promoting employment and self employment and programs to increase social inclusion (AEP, 2007-2013). The Employment Service of Slovenia spent 32.7\% of its $€ 28,598,048$ (2009) budget on active employment policies (Zavod RS za zaposlovanje, 2010).

Part of the attention in the AEP program is also given to tackle youth employment. Thus, the main substantive attention in 2010 is, among others, focused on operations to promote the establishment of scholarships, the promotion of employment of young first job seekers, and some other measures that also affect young people, i.e., the promotion of employment of disadvantaged persons, promoting the creation of new jobs, boosting the development of new employment programs for the most vulnerable people in the labor market, developing new opportunities for job creation and others.

The likelihood of including young people into employment programs decreases with age, where this probability is greater for women than for men. Young men are employed faster and sooner and enter into the labor market before young women do. There is also a hidden discrimination that puts young women in a subordinate position, resulting in a long time looking for employment. In addition, the subsequent integration into the labor market is also linked to the decision of having a family (Rotar, 2008).

In 2009 , there were 9,922 people who are searching for their first employment included into the active employment policy programmes, and there were also 11,104 young people (below 26 years) included into these same programmes (some are counted in both categories) (Zavod RS za zaposlovanje, 2010).

Young people are particularly exposed to the program of the third measure, i.e., the promotion of 
employment and self-employment, in which incentives are implemented in the form of subsidies for the employment of disadvantaged groups. Here, the Ministry of Labour, Family and Social Affairs carried out a pilot project "Graduate, Activate and Employ Yourself", which will be further described below. Within the Active Employment Policy programmes for young people, there will also be carried out the project "Employ.me", which is described in the following part of the paper.

\section{The Project “Graduate, Activate and Employ Yourself”}

In September 2009, the Employment Service of Slovenia announced a public tender for the project "Training of Graduates in the Workplace and the Subsidy for Employment of Graduates - Graduate, Activate and Employ Yourself". The invitation to tender was implemented under the Operational Programme Human Resources Development for 2007-2013, under the second development priority "Promoting employability and inactive job seekers". The project aims at mobilizing students during graduation to enable them to undergo training in the workplace and to gain the knowledge and skills to facilitate the integration into work as well as promoting the employment of graduates after training for the same employer through an employment subsidy. Training lasts from one to six months. Employers are reimbursed for eligible costs of training graduates as the grant of $€ 2,000$ is awarded to employers for employment of graduates for full-time for at least six months (Zavod RS za zaposlovanje, 2010).

It is an innovative project that aims to improve employment opportunities for graduates and increase their competitiveness in the labor market. The program should, among others, prevent the transition of young people to open unemployment and contribute to the efficient integration of graduates into the labor market. It will also ensure the integration of economic and educational spheres and also enable the creation and strengthening of social networks for graduates, and thus indirectly shorten the study and more rapidly integrate the young into the labor market (Zavod RS za zaposlovanje, 2009). The project is partly financed from the state budget, and partly funded by the European Union through the European Social Fund. In 2010, the project has intended projected budget of $€ 39.2$ million and $€ 23.9$ million in 2011 (Ministry of Labour, Family and Social Affairs, December 15, 2009).

\section{The Project "Employ.Me”}

In the context of the AEP program, young people are especially included into training at the workplace, in order to enable them to obtain relevant work experience and subsidized employment through public tenders via the project "Employ.me". In 2009, there were 2,904 people involved in this program, of which there were 944 below 26 years of age.

On March 19, 2010, the Employment Service of Slovenia published a public tender for "Employ.me" which offers a subsidy for employment of target groups, i.e., unemployed youth seeking their first job, the elderly, those with lower education and those who are among the registered unemployed for the previous 12 months or more. The subsidy amounts to $€ 4,000$ and is paid after the recruitment of unemployed persons. The employer must enter into a full-time employment contract with its new employee and keep the new employee for at least one year. For the period of 2010-2011, there is $€ 18$ million for the tender: Eighty five percent of these funds are supplied by the European Union through the European Social Fund (ESF) under the Operational Programme for Human Resources Development in Slovenia for the period of 2007-2013. The remaining 15\% is provided from the state budget. The tender provides for the employment of 4,500 unemployed persons. The young people in this project account for three out of six target groups, i.e., younger than 25 years (who in the 
previous six months did not have a regular paid employment), first-time job seekers (who have acquired professional or vocational education less than two years ago and are reported in the records of ESS for at least six months), younger than 30 years (with at least a university degree, a suitable profession and without regular paid employment in the last six months) (Zavod RS za zaposlovanje, 2010).

\section{Conclusion}

Using the full potential of young people and creating a favorable environment in which young people can develop their skills, work and participate actively in society is essential for the economic and social development of the country. This is especially true considering the fact that the economy is knowledge-based, and that we live in an aging society in which it is essential to give all young people the opportunity to fully develop their potential. Labour markets urgently need to respond to these challenges to use the potential of the youth population.

Youth unemployment has long been perceived as a temporary phenomenon in the transition from school to work. However, in the changing demographic and economic context, we must rethink youth employment problems and the risks that it could cause (COM, 2007).

For the actual situation of young people following the completion of education in the labor market, the unemployment rates are not the only important indicator of unemployment, but also the question of whether they have managed to get jobs that are appropriate for their qualifications (regarding the complexity and scope of work). For an overall assessment, it is therefore necessary to analyze the quality of their employment. Only in this case, is it expected that the investment in education of these people is in fact recovered through an appropriate increase of value added in the economy (Versa \& Spruk, 2004). We have to highlight the enlightened attitude of employers to employment in terms of the social responsibility to provide opportunities for young people and the attitude of trade unions, which may bring public attention to the problem and its involvement in social negotiations and discussions on these issues (Ignjatović \& Trbanc, 2009).

Young people today face many complex challenges. Searching for solutions to increase employability is only one aspect of a much wider problem in the labor market. It is important not only to narrow search channels to raise the employability of young people, but also to broader the search for multidimensional measures that enable young people to get good and decent employment, and conditions that will enable them to find their place in society, achieve independence and realize their personal aspirations.

The issue of young people in the labor market is extensive and requires comprehensive investigation. In this article, we have highlighted only some of them. The paper does not cover the role of grants and scholarships in the education and their impact and connection with the recruitment of young people. We have also touched the problem of employment for youth with special needs, which is a specific group of young people and requires much attention.

\section{References}

Active Employment Policy Programme for the period 2007-2013. (2010). Retrieved June 4, 2010, from http://www.ess.gov.si/slo/Dejavnost/Programi/apz_2007_2013.pdf

Baloh, P. S. (2003). Labour market indicators. Statistični dnevi Radenci, November 24-26, 2003, In Slovenian.

Blanchard, O. (2005). European unemployment: The evolution of facts and ideas. NBER Working paper No. 11750. Cambridge, London.

Boljka, U. (2009). Demographic characteristics of youth and fertility problem. In U. Boljka, \& T. Rakar (Eds.), Between childhood 
and adulthood: Analysis of situation of the youth in Slovenia 2009. Ljubljana: Ministry of Education and Sport, Office of the Republic of Slovenia for Youth: Social Protection Institute of the Republic of Slovenia, In Slovenian.

Ćeklić, B., Kramer, Lukiĉ, A. G., Milić, B., Miloševiĉ, V., \& Silaj, T. (2008). Youth employment strategy in the knowledge society (2nd ed.). Knjiga, Strategija. Študentska organizacija Slovenije.

COM. (2001). European commission white paper. A new impetus for European youth. Retrieved June 14, 2010, from http://www.ursm.gov.si/fileadmin/ursm.gov.si/pageuploads/doc/Bela_knjiga.soc

COM. (2007). Report from the Commission to the European Parliament, the Economic and Social Committee and the Committee of the Regions: Promoting young people's full participation in education, employment and society. Retrieved June 16, 2007, from http://www.ursm.gov.si/.../Sporocilo_komisije_o_polni_participaciji_mladih.doc

Fergusson, D. M., John Horwood, L., \& Woodward, L. J. (2001). Unemployment and psychosocial adjustment in young adults: Causation or selection? Social Science \& Medicine, 53, 305-320.

Ignjatović, M., \& Trbanc, M. (2009). Employment and unemployment among young people: Active, flexible and adaptable. In U. Boljka, \& T. Rakar (Eds.), Between childhood and adulthood: Analysis of situation of the youth in Slovenia 2009. Ljubljana: Ministry of Education and Sport, Office of the Republic of Slovenia for Youth: Social Protection Institute of the Republic of Slovenia.

Institute RS of Macroeconomic Analysis and Development. (2010). Spring Forecast of Economic Trends 2010. UMAR, Ljubljana, Slovenija.

Južnik, R. L. (2008). Inclusion of young unemployed persons into active labour market policies. NG, št. 1-2/2008.

Kuhar, M. (2009). Transitions of youth in adulthood. Retrieved June 12, 2010, from http://www.mladinski-delavec.si/datoteke/mdnfi/images/02-01.pdf

Ministry of Education and Sport. (2007). Slovene education system in numbers. Redaction EUTRIP. Ljubljana: Ministry of Education and Sport.

Ministry of Labour, Family and Social Affairs. (2009). The plan of implementation of active employment policy measures for 2010 and 2011. Retrieved December 15, 2009, from http://www.mddsz.gov.si/fileadmin/mddsz.gov.../15122009_APZ-2010.docx

Rapuš, P. J. (2005, September). Vulnerability of young people facing unemployment. Socialna Pedagogika, 9(3), 329-340. Retrieved June 16, 2010, from http://www.zzsp.org/revija/2005/05-3-329-360.pdf

Rener, T. (2007). Globalisation, individualisation and social exclusion of youth. UMAR, IB revija 2/2007, 40-49.

Ribar, D. C. (2001) The effects of local employment opportunities on youths' work and schooling. Economics of Education Review, 20, 401-413.

Statistical Office of the Republic of Slovenia. (2009). Youth in Slovenia. Retrieved June 16, 2010, from http://www.stat.si/doc/pub/mladi2009-SLO.pdf

Sullivan, A., \& Sheffrin, S. M. (2003). Economics: Principles in action, upper saddle river. New Jersey: Pearson Prentice Hall.

Trbanc, M. (2007a). The way of young people into employment: Comparison of Slovenia with other EU countries. In Anton Kramberger in Samo Pavlin (Ed.), Employability in Slovenia: An analysis of transition from school to work: State, predictions, comparisons, 38-62. Ljubljana: Fora.

Trbanc, M. (2007b). Employment and unemployment of young people. Retrieved June 8, 2010, from http://www.guidance-europe.org/country/SLOVENIA/KARIERA/karieraa/zaposlovanjetrbanc/zapo

Ule, M. (2007). Youth and social changes. UMAR, IB revija 2/2007, 62-69.

Vaupotič, K., Lukić, K., Bajde, V., Perko, V., \& Golob, M. (2007, April). Existing support mechanisms and measures for youth employment. Regionalni sklad dela Podravje, Maribor.

Verša, D., \& Spruk, V. (2004, Avgust). Young graduates in the labor market. Zavod RS za zaposlovanje, Ljubljana.

Vertot, P. (2009). Youth in Slovenia. Statistical Office of the Republic of Slovenia, Ljubljana.

Zavod RS za zaposlovanje. (2009). Training of graduates in the workplace and the subsidy for employment of graduates /Absolvent-Aktiviraj In Zaposli Se! Retrieved June 13, 2010, from http://www.ess.gov.si/slo/dejavnost/javnirazpisi/04-09-09absolventi/04-09-09JavniRazpis.pdf

Zavod RS za zaposlovanje. (2010). Zaposli.me/Javni razpis za spodbujanje zaposlovanja težje zaposljivih brezposelnih oseb. $\begin{array}{llll}\text { Retrieved June } & 13, & 2010, & \text { from }\end{array}$ http://www.ess.gov.si/slo/Dejavnost/JavniRazpisi/19-03-10ZaposliMe/19-03-10ZaposliMe.htm 


\section{Appendix A: Legislation in the Field of Employment in Slovenia}

For the situation of youth in the labor market, legal and executive employment regulation is also very important, and it sets the conditions of employment and redundancy (types of contracts, rights and obligations, permitted forms of youth work etc.), and establishes levels of employment flexibility (Ignjatovič \& Trbanc, 2009).

The most important laws governing the labor market in Slovenia are as follows:

- The currently valid act governing the labor relations in Slovenia is the Employment Relationship Act (Zakon o delovnih razmerjih, Ur.1. RS, 42/2), which entered into force on Juanary 1, 2003. It is the main law for all employment relationships in the economy;

- Another important act in the employment area is the Employment and Insurance against Unemployment (Zakon o zaposlovanju in zavarovanju za primer brezposelnosti, Ur.l. RS, št. 107/2006). This act regulates the employment, unemployment insurance, management system and method of implementation of technical tasks in this field. This act also regulates scholarships and student work. Employment under the Employment and Insurance against unemployment act covers employment supply, work interference, measures to promote employment and creation of new jobs and the maintenance of productive jobs, and all those activities that provide the conditions for productive and freely chosen employment, career and professional development, and application of individuals' working skills;

- The area of collective agreements and collective collusions is covered by the Collective Agreements Act (Zakon o kolektivnih pogodbah, Ur.l. RS, št. 43/2006).

\section{Appendix B: The Structure of Slovenia's Education System}

In Slovenia, education begins with preschool education. Children from the age of one and until they go to primary school are enrolled in nursery school, but enrolment is not obligatory. When children reach the age of six, they enroll in a nine-year elementary school which is obligatory and is divided into three-year cycles. After elementary school, they can continue with secondary education. Secondary education is divided into technical and vocational education (secondary technical and professional, secondary vocational, vocational technical, and short-term vocational), and general secondary education (general and technical "gimnazija"). Higher education is divided into three levels. The first level includes vocational higher education study programs and university study programs. The second level comprises Master's study programs and the third level is the Doctoral study programs. It is important to note that the structure of higher education changes after the amendments to the Higher Education Act in 2004. Until then, higher education had two levels, i.e., the undergraduate and the postgraduate levels (pre-Bologna programs). Part of tertiary education is also a post-secondary vocational education which is defined as short-term higher education. The study programs are extremely practice-oriented (Ministry of Education and Sport, 2007).

Higher education falls within the competence of the Ministry of Higher Education, Science and Technology, while elementary and secondary education is within the competence of the Ministry of Education and Sport.

Youth in Slovenia remain in education the longest compared to other EU countries and the proportion of young people who enter into higher education is among the highest in the EU. However, the student dropout rate is almost one third, and the average graduation time is more than seven years. Therefore, it seems that higher education does not meet most of its basic purpose, sometimes even looks like that entering into higher education even serves primarily as a kind of incubator, allowing postponement of entry into the uncertain job market (Kuhar, 2009). 